\title{
The Relationship Between Social Skills and Psychosocial Adjustment Among Those who Care for Older Adults
}

\author{
Francine Náthalie Ferraresi Rodrigues Queluz ${ }^{1}$ (D) https://orcid.org/0000-0002-8869-6879 \\ Elizabeth Joan Barham² (D) http://orcid.org/0000-0002-7270-4918 \\ Zilda Aparecida Pereira Del Prette ${ }^{2,3}$ (D) https://orcid.org/0000-0002-0130-2911
}

\begin{abstract}
Many caregivers of older adults report distressing interpersonal difficulties. Training in social skills could be a valid strategy for helping these people. In this study, evidence was examined concerning the relationship between the social skills repertoire of caregivers of older adults and indicators of their psychosocial adjustment. Based on a literature review in seven databases, using search terms in Portuguese, English and Spanish, 11 articles on this relationship were found, published by November, 2016. It was observed that: (1) the study of social skills in caregivers of older adults is recent; (2) caregivers who used social skills more often felt less burdened; and (3) social skills can strengthen the interpersonal relationships of caregivers, contributing to better psychosocial adjustment. Thus, it may be useful to develop and evaluate programs to promote the use of social skills in this context, to verify the impacts of improved social skills on caregivers' well-being.
\end{abstract}

Keywords: caregivers, aging, assertiveness, quality of life, stress

\section{A Relação Entre as Habilidades Sociais de Cuidadores de Idosos e seu Ajustamento Psicossocial}

\begin{abstract}
Resumo: Muitos cuidadores de idosos relatam dificuldades interpessoais desgastantes e o treinamento em habilidades sociais junto a essas pessoas pode ser uma estratégia válida. Esse estudo objetivou examinar evidências sobre a relação entre o repertório de habilidades sociais de cuidadores de idosos e indicadores de seu ajustamento psicossocial. Por meio de um levantamento bibliográfico em sete bases de dados, usando termos de busca em português, inglês e espanhol, foram encontrados 11 artigos, publicados até novembro de 2016. Observou-se que: (1) o estudo de habilidades sociais em cuidadores de idosos é recente; (2) cuidadores que usavam habilidades sociais mais frequentemente se sentiam menos sobrecarregados; e (3) as habilidades sociais podem fortalecer as relações interpessoais dos cuidadores, contribuindo para um melhor ajustamento psicossocial. Concluiu-se que pode ser útil desenvolver e avaliar programas para promover o uso de habilidades sociais neste contexto, verificando os impactos da melhora nas habilidades sociais de cuidadores no seu bem-estar.
\end{abstract}

Palavras-chave: cuidadores, envelhecimento, assertividade, qualidade de vida, estresse

\section{La Relación entre las Habilidades Sociales de Cuidadores de Ancianos y su Ajuste Psicosocial}

\begin{abstract}
Resumen: Muchos cuidadores de ancianos relatan dificultades interpersonales agotadoras, y el entrenamiento en habilidades sociales junto a esas personas les puede resultar en una estrategia válida. El presente estudio propone examinar las evidencias sobre la relación entre el repertorio de habilidades sociales de cuidadores de ancianos y los indicadores de su ajuste psicosocial. Se hizo una recogida bibliográfica en siete bases de datos utilizando los términos de búsqueda en portugués, inglés y español; y se encontró 11 artículos publicados hasta noviembre de 2016. Se observó que: (1) el estudio de las habilidades sociales de los cuidadores de ancianos es reciente; (2) los cuidadores que usaban habilidades sociales con más frecuencia se sentían menos sobrecargados; y (3) las habilidades sociales pueden fortalecer las relaciones interpersonales de los cuidadores y contribuir a un mejor ajuste psicosocial. Se concluyó que pueden ser útiles el desarrollo y la evaluación de programas para promover el uso de habilidades sociales en este contexto verificando los impactos en la mejora de las habilidades sociales de cuidadores en su bienestar.
\end{abstract}

Palabras clave: cuidadores, envejecimiento, asertividad, calidad de vida, estrés

${ }^{1}$ Universidade São Francisco, Campinas-SP, Brazil

${ }^{2}$ Universidade Federal de São Carlos, São Carlos-SP, Brazil

${ }^{3}$ Instituto Nacional de Ciência e Tecnologia sobre Comportamento, Cognição e Ensino, São Carlos-SP, Brazil

This article derives from the doctoral thesis of the first author, supervised by the second and third authors, and defended in 2016, in the Graduate Program in Psychology at the Universidade Federal de São Carlos. Support: FAPESP, CAPES, CNPq and São Paulo Research Foundation (FAPESP Grant \# 2012/00907-3) and CNPq (Grant \#306002/2017-5 and 405658/2016-).

Corresponding address: Francine Náthalie Ferraresi Rodrigues Queluz. Universidade São Francisco. Psicologia. Campinas-SP, Brazil. E-mail: francine.queluz@gmail.com
Caring for dependent older adults involves many demands that are managed via investments in physical adaptations to their living environment and assistance from health care professionals, but little has been done to address the interpersonal tensions that affect the psychosocial environment in which caregiving occurs. The interpersonal difficulties reported by caregivers (Pinto, Barham, \& Del Prette, 2016) point to the fact that, in addition to dealing with problems that affect daily routines, mobilizing others to get involved in caring for older family members can be 
an exceptionally difficult task, which leads to the question of how to improve this situation.

Even among caregivers who have access to medications, assistive technologies and professional services that help their older relative manage increasing health problems, researchers continue to report that taking care of an older relative for an extended period of time often generates stress, resulting in a sense of being overburdened (Pinquart \& Sörensen, 2011; Wang, Robinson, \& Carter-Harris, 2014; Zwaanswij, Peeters, van Beek, Meerveld, \& Francke, 2013), and a decrease in the quality of the caregivers' lives (Yıkılkan, Aypak, \& Görpelioğlu, 2014). Often, significant tensions arise in relationships with other people who are part of the caregiver's life, generating a negative emotional environment (Pinto, Barham, \& Albuquerque, 2013; Pinto et al., 2016). Thus, although taking care of a frail older relative is socially expected and valued, we also know that those who are caregivers systematically report poorer physical and mental health when compared to people of the same age and sex who do not care for older individuals (Tomomitsu, Perracini, \& Neri, 2014). For many caregivers, this involvement is marked by higher rates of depression, higher perceptions of burden, an increased probability of acquiring coronary diseases, increased social isolation and greater financial pressures (Grossman \& Gruenewald, 2017; Wang et al., 2014; Yıkılkan, et al., 2014).

Based on their meta-analysis of the results of intervention programs to work on stress management skills or to offer support to family caregivers of older adults with a mental disorder, Weinbrecht, Rieckmann, and Renneberg (2016) showed that these efforts bring important but modest results. Another way to reduce some of the negative psychological consequences of caregiving may be through focusing on social skills (SS). In other populations, individuals who have well-developed social skills tend to find ways to integrate and meet the needs of the people who are part of their daily lives, enabling them to maintain positive relationships (A. Del Prette \& Z.A.P. Del Prette, 2017). As such, one would predict that social skills may be a critical factor that permits those who care for a dependent older adult to experience gains, such as a greater sense of attachment to the older adult, a sense of well-being, a sense of satisfaction related to managing this responsibility, greater contact with other relatives, among others (Grossman \& Gruenewald, 2017). According to Pearlin, Mullan, Semple, and Skaff's (1990) theory of stress, the caregivers' coping strategies, along with support from their social network, affect their resilience and efficiency when managing the demands of caring for an older individual (Garces et al., 2012; Li et al., 2012).

Caregivers need to construct coping strategies that help them deal with the changing demands and needs not only of the person they care for, but that also reflect changes in their own abilities and in the needs of the other people who are involved in their lives ( $\mathrm{Li}$ et al., 2012). To be effective, coping strategies may require problem-solving skills, social skills (such as empathy, communication skills, and the ability to work cooperatively with others), and the ability to handle differences of opinion in a respectful and assertive manner (Bandeira, Tostes, Santos, Lima, \& Oliveira, 2014). For example, caregivers may need to: find ways to encourage older relatives to alter routines, to adjust to their declining health; to ask family members for additional help as the demands of caregiving increase; to use conversational skills with an older person who dwells on losses, by discussing more positive situations; and to comfort and strengthen the elderly person when friends or family members die. As these examples illustrate, social skills can help caregivers to mitigate the psychological impacts of difficulties that arise in the older adult's life (Broese van Groenou, de Boer, \& Iedema, 2013).

Based on Pearlin et al. (1990) model, one can postulate that the development of social skills that are appropriate to the context of caring for an older person could act as a mediating factor, affecting the caregiver's degree of success in managing thoughts and reactions about other people, that generate perceptions of stress. Moreover, beyond stress management, caregivers' social skills may be important to their overall wellbeing, given findings from other studies that demonstrate that the use of social skills is associated with a higher quality of life, and with lower rates of anxiety and depression (A. Del Prette \& Z.A.P. Del Prette, 2017; Scheufler et al., 2017).

The concept of social competence involves an assessment or judgment regarding the appropriateness of a person's behavior, considering the effects that it produces on completing important tasks with others, and on the long-term well-being of all those who are working together (A. Del Prette \& Z.A.P. Del Prette, 2017). As such, social competence requires gaining knowledge about different ways to accomplish a given task, as well as discovering effective ways to engage people who could contribute to accomplishing this task.

For A. Del Prette and Z.A.P. Del Prette (2017), a welldeveloped social skills repertoire includes ten classes of social behaviors: communication (asking or answering questions, asking for or providing feedback, starting or ending a conversation); civility (saying please or thank you, apologizing, greeting people); assertiveness (expressing opinions, indicating agreement or disagreement, talking to someone in authority, expressing annoyance, requesting a change of behavior, or dealing with criticism); empathy (noticing how another person feels, offering support); friendliness (spending time with others, exchanging confidences, keeping in touch); ability to work with others (coordinating groups, organizing activities, mediating conflicts); capacity to express solidarity (sharing, cooperating, helping those in need); ability to solve interpersonal conflicts (identifying problems, staying in control of one's emotions, making choices); ability to express affection or love (smiling, showing concern for the other's well-being, touching, sharing thoughts and feelings); and ability to speak in public (speaking so one can be heard, making eye contact with those one is speaking to, engaging with the audience).

Corroborating social learning theories, researchers have shown that social skills are learned in three ways: (a) as a result of the consequences that follow social behaviors; (b) through direct instruction or teaching; (c) by observing others. These skills are crucial for the development and maintenance of interpersonal relationships. Non-adaptive behaviors, related to fear and anxiety, are learned from interactions with authoritarian models during the developmental process, 
leading to avoidant behaviors when facing demands to express emotions, interact with others, express opinions, among other demands. Instead of more appropriate responses, the individual learns to engage in behaviors that do not solve the problem, but that reduce short term anxiety and frustration, such as aggressive antisocial responses, and the abuse of alcohol or other psychoactive substances (A. Del Prette \& Z.A.P. Del Prette, 2017).

Researchers who have studied the relationship between social behavior and psychosocial adjustment in the older adult population have observed that those who can better express themselves and who have good interpersonal relationships are healthier and less prone to diseases (Carneiro \& Falcone, 2013; A. Del Prette \& Z.A.P. Del Prette, 2017; Scheufler et al., 2017). Furthermore, having access to social support in difficult situations contributes to higher self-esteem, more positive perceptions of self-efficacy and a more positive identity (Grossman \& Gruenewald, 2017; Tolkacheva, Broese van Groenou, \& van Tilburg, 2014).

Consequently, studying the social skills of those who care for older adults could contribute to helping caregivers use interpersonal skills that improve their ability to find socially appropriate ways of responding to ongoing changes in what their older relative can do, as well as managing relationships with other family members and any paid workers who may be involved in the caregiving context. Therefore, to determine if it might be useful to offer a social skills training program that would address the specific social interaction problems faced by those who care for older family members, and given the association established in the literature between social skills and a better quality of life in other social contexts, in this study, evidence concerning the relationship between caregivers' social skills and indicators of their psychosocial adjustment was examined.

\section{Method}

A literature search was conducted in seven databases: PsychInfo, Lilacs, Scielo, Gerontological Society of America, MedLine, Redalyc and the CAPES thesis database, considering all studies publish up until November 2016. The following search terms were used, in Portuguese, English and Spanish: social skills, social skill, assertiveness, interpersonal relationships, or social competence, paired with caregiver, caregivers, aging, elderly and older person. This search led to the identification of 356 studies.

We excluded studies that were not about caregiving and social skills (256 studies), or studies that focused on those who cared for someone with cancer, autism, HIV or psychiatric diseases among people who were not older adults (89 studies). In other words, studies were only selected if the authors discussed social skills among caregivers for older adults.

\section{Results}

The eleven studies that addressed the topic of social skills among caregivers for older adults included nine articles and two Master's theses. The earliest study was published in 1988. Five studies were published in Brazil, three in the United States, two in Spain and one in Germany. Analyzing the dates of publication in Table 1, it can be noted that the number of studies on social skills among those who care for older adults has increased recently. Most articles were published in the last seven years, and four were published as recently as 2014 .

Table 1

Titles of Studies About Social Skills Among Those who Care for Older Adults, Published Between 1988-2016

\begin{tabular}{ll}
\hline Title & Authors \\
\hline A social skills training program for adult caregivers & Robinson (1988) \\
The relationship between social skills, social support, self-esteem, and burden in adult caregivers. & Robinson (1990) \\
Effects of two caregiver training programs on burden and attitudes toward help & Robinson and Yates (1994) \\
$\begin{array}{l}\text { Evaluation of assertiveness as a predictor of burden among caregivers for Alzheimer's patients } \\
\text { Caregivers of the elderly with Alzheimer's disease: Effects of psychoeducational groups and }\end{array}$ & Muela, Torres, and Peláez (2001) \\
$\begin{array}{l}\text { individualized, in-home support } \\
\text { A psycho educational intervention program for caregivers of patients with dementia }\end{array}$ & Faleiros (2009) \\
$\begin{array}{l}\text { Assessment of self-perceived social competency of caregivers in dementia care: Development and (2010) } \\
\text { psychometric testing of the SOKO dementia }\end{array}$ & Franzmann, Krause, Haberstroh, and \\
$\begin{array}{l}\text { Development of a psychoeducational program in emotional intelligence for primary caregivers of } \\
\text { Alzheimer patients }\end{array}$ & Maciá and López (2014) \\
$\begin{array}{l}\text { Psychological wellbeing: Comparing caregivers who assisted dependent older adults, with and } \\
\text { without dementia }\end{array}$ & Pinto and Barham (2014a) \\
$\begin{array}{l}\text { Social skills and coping strategies: Relationships with psychological wellbeing among caregivers } \\
\text { of elderly people with high dependency }\end{array}$ & Pinto and Barham (2014b) \\
\begin{tabular}{l} 
Interpersonal conflicts among family caregivers of the elderly: The importance of social skills \\
\hline
\end{tabular} & Pinto et al. (2016)
\end{tabular}




\section{Objectives of the studies}

The objectives of the studies discussed in this review are presented in Table 2. Except for three studies, most researchers investigated the influence of social skills on perceptions of burden among caregivers for older adults. Franzmann et al.'s (2014) study, however, involved the validation of a scale for caregivers working in institutions, and caring for older adults with dementia. To evaluate construct validity, the authors tested the relationship between scores on their scale of social competence and perceptions of stress. Pinto et al. (2016) reported the results of a qualitative study in which they asked caregivers, older adults and professionals in the field of Gerontology to identify the primary conflicts involved in the task of caring for an older relative, as well as the social skills they considered to be important in this role. Maciá and López (2014) investigated the relationship between social skills and emotional intelligence among caregivers.

Table 2

Objectives of the Studies on Caregivers' Social Skills

\begin{tabular}{|c|c|}
\hline Objectives & Authors \\
\hline $\begin{array}{l}\text { To verify if caregivers in a group that received SS training had lower perceptions of } \\
\text { burden than caregivers in a control group. }\end{array}$ & Robinson (1988) \\
\hline $\begin{array}{l}\text { To verify the relationship between social skills and self-esteem, social support and } \\
\text { burden. }\end{array}$ & Robinson (1990) \\
\hline $\begin{array}{l}\text { To verify what type of intervention gave more benefits to the caregivers: a behavioral } \\
\text { management program or a SS training program. }\end{array}$ & Robinson \& Yates (1994) \\
\hline $\begin{array}{l}\text { To verify if there was a relationship between caregivers' assertiveness and their } \\
\text { perceptions of burden. }\end{array}$ & Muela et al. (2001) \\
\hline $\begin{array}{l}\text { To verify if a group that received psychoeducational support (including SS training) and } \\
\text { help in using these concepts would have lower perceptions of burden, fewer symptoms } \\
\text { of depression and better quality of life, compared to a control group. }\end{array}$ & Faleiros (2009) \\
\hline $\begin{array}{l}\text { To evaluate the impact of an in-home intervention program on perceptions of burden, } \\
\text { social skills and stress reported by caregivers. }\end{array}$ & Dornelles (2010) \\
\hline $\begin{array}{l}\text { To evaluate the psychometric evidence of a questionnaire to measure social competence } \\
\text { among paid caregivers of institutionalized older adults with dementia. }\end{array}$ & Franzmann et al. (2014) \\
\hline $\begin{array}{l}\text { To identify the influence of social skills and emotional intelligence on caregivers of } \\
\text { older adults with Alzheimer's disease, and evaluate the impact of an intervention } \\
\text { program offered to caregivers. }\end{array}$ & Maciá \& López (2014) \\
\hline $\begin{array}{l}\text { To compare two groups of caregivers (one with people who were taking care of a } \\
\text { dependent but lucid, older family member, and a second with people who took care of } \\
\text { older relatives who were dependent and had dementia), regarding their perceptions of } \\
\text { burden, quality of their relationship with their older relative, coping strategies and SS of } \\
\text { the caregivers. }\end{array}$ & Pinto \& Barham (2014a) \\
\hline $\begin{array}{l}\text { To verify the relationship between SS and coping strategies, perceptions of burden, and } \\
\text { quality of the relationship. }\end{array}$ & Pinto \& Barham (2014b) \\
\hline $\begin{array}{l}\text { To identify the main conflicts involved in the task of caring for an older relative and to } \\
\text { identify the SS considered to be important to accomplish this task. }\end{array}$ & Pinto et al. (2016) \\
\hline
\end{tabular}

\section{Psychosocial variables related to social skills}

Table 3 presents information on the psychosocial variables potentially related to social skills and to social competence. In the studies examined, the relationship between social skills and perceptions of burden was the outcome variable most frequently evaluated. In three studies (Faleiros, 2009; Maciá \& López, 2014; Robinson \& Yates, 1994), the researchers did not use scales to evaluate the caregivers' social skills, although they offered social skills training and evaluated whether their intervention program led to improvements in caregivers' perceptions of burden (Faleiros, 2009; Robinson \& Yates, 1994), to a reduction in symptoms of depression, and to perceptions of higher quality of life (Faleiros, 2009). Finally, Pinto et al. (2016) examined the conflicts that caregivers most commonly report, in the context of caring for their older family member, and the social skills that the caregivers thought were useful in handling these conflicts. 
Table 3

Other Constructs, Related to Caregivers' Social Skills

\begin{tabular}{ll}
\hline Evaluated variables & Authors \\
\hline Burden, self-esteem and social support & Robinson (1988) \\
Burden, self-esteem and social support & Robinson (1990) \\
Burden & Robinson and Yates (1994) \\
Burden & Muela et al. (2001) \\
Burden, depression and quality of life & Faleiros (2009) \\
Burden and stress & Dornelles (2010) \\
Stress & Franzmann et al. (2014) \\
Emotional intelligence & Maciá and López (2014) \\
Burden, coping and quality of the relationship & Pinto and Barham (2014a) \\
Burden, coping and quality of the relationship & Pinto and Barham (2014b) \\
Conflicts & Pinto et al. (2016) \\
\hline
\end{tabular}

\section{Caregiver characteristics and study design}

The number of participants in each of the studies ranged from 5 (Dornelles, 2010) to 172 (Franzmann et al., 2014). All participants were caregivers for older adults, and in all studies, most caregivers were middle-aged women. In most studies, caregivers were family members (Dornelles, 2010; Faleiros, 2009; Maciá \& López, 2014; Muela et al., 2001; Pinto \& Barham, 2014a, 2014b; Robinson, 1988, 1990). In Robinson's (1988) study, the sample included 17 family and 3 paid caregivers. However, according to the authors, the paid caregivers acted as if they were family members. In Franzmann et al.'s (2014) study, all caregivers were paid, i.e., formal caregivers working in an institutional care setting. Finally, in Pinto et al.'s (2016) multi-informant study, in addition to family caregivers, participants also included elderly care recipients and professionals who worked in the field of aging (doctors, nurses, psychologists, social workers and physical therapists).

Regarding care recipients, all studies included caregivers who assisted older adults with dementia, and most cared for a relative with Alzheimer's disease. Pinto and Barham (2014a, 2014b) investigated perceptions of burden among caregivers of highly dependent older adults, comparing those who cared for a relative who had dementia with those caring for a relative who did not have dementia. In Pinto et al.'s (2016) study, participants included caregivers of any older family member, whether or not this person had dementia.

Finally, four of the studies were correlational in nature (Franzmann et al., 2014; Muela et al., 2001; Pinto \& Barham, 2014b; Robinson, 1990), five involved the assessment of intervention programs (Dornelles, 2010; Faleiros, 2009; Maciá \& López, 2014; Robinson 1988; Robinson \& Yates, 1994), five presented comparisons between groups (Faleiros, 2009; Maciá \& López, 2014; Pinto \& Barham, 2014a; Robinson, 1988; Robinson \& Yates, 1994), and one was a qualitative research study (Pinto et al., 2016).

\section{Evidence about social skills and psychosocial well-being}

Table 4 shows the empirical evidence about the use or effects of social skills as reported in the studies that were analyzed. In four of the studies (Dornelles 2010; Faleiros, 2009; Robinson, 1988; Robinson \& Yates, 1994), the authors evaluated the effects of a social skills training program for caregivers. At the end of the intervention program, the caregivers reported lower perceptions of burden than they reported during the pre-program phase, based on a baseline assessment. In the studies conducted by Muela et al. (2001), Pinto and Barham (2014a, 2014b) and Robinson (1990), more frequent use of social skills was associated with higher quality interpersonal relationships.

Although, chronologically, it was one of the most recent studies, Pinto and Barham (2014b) were the first to verify the strength of the relationship between social skills and other constructs, including perceived burden and quality of the relationship between the caregiver and the carereceiver. These authors observed that: (a) caregivers with higher social skills scores, especially those who were able to control aggressive reactions, reported lower perceptions of burden; (b) caregivers who reported expressing positive feelings more often indicated fewer tensions and conflicts in the relationship with their elderly relative; (c) caregivers who could set limits on what they would do rated their relationship with their older family member as being more positive; (d) caregivers who rated their interactions as being more positive reported better quality relationships with the older adult. Muela et al. (2001) and Robinson (1990) observed that caregivers who were more assertive had lower perceptions of burden and received more social support. Franzmann et al. (2014) also found that socially competent, paid care providers had lower perceptions of stress related to caring for an older adult. However, in the opposite direction, Muela et al. (2001) reported that less assertive caregivers had lower perceptions of subjective burden. According to Muela et al., caregivers who do not feel burden would not need to develop their assertiveness 
skills to get help, but they also suggested that further studies must be conducted to better understand this issue.

Turning to the findings reported in intervention studies, these programs were based on the assumption that social skills are important for those who care for an older adult. Dornelles (2010), Faleiros (2009), Robinson (1988) and Robinson and Yates (1994) evaluated the impact of offering social skills training to caregivers on their perceptions of caregiver burden. Robinson (1988) presented results indicating that the caregivers in their training program learned to better use social skills, and that they reported lower perceptions of burden when compared to a group of caregivers who did not participate in the intervention program. Faleiros (2009) showed that an intervention program focused on assertive social skills training increases the ability of the caregiver to deal with people who are engaged in their daily routines, in a constructive way. Likewise, caregivers who participated in Dornelles' (2010) intervention study reported increases in the frequency of the use of social skills by the caregivers (praising others, accepting praise, and expressing negative feelings in a constructive manner), as well as reductions in perceived levels of burden. Robinson and Yates (1994) found that caregivers who received training in either social skills or in behavioral management strategies experienced a decrease in perceptions of burden, used more positive strategies to ask for help, and were more likely to use paid care services for their older relative. The authors reported no differences between the two training programs (social skills or behavioral management strategies). Maciá and López (2014) did not find a significant influence of social skills training on a measure of emotional intelligence. However, caregivers reported feeling more prepared for the daily activities related to caring for their older relative. Finally, Pinto et al. (2016) found that the social skills considered most important were expressing positive feelings, controlling aggressiveness, and discussing problems.

Table 4

Evidence Obtained Regarding Caregivers' Use of Social Skills

\begin{tabular}{|c|c|}
\hline Evidence & Authors \\
\hline $\begin{array}{l}\text { Caregivers who received social skills training had lower perceived burden when compared to the group that } \\
\text { received no training in SS (control group). }\end{array}$ & Robinson (1988) \\
\hline Caregivers with lower perceptions of subjective burden had a higher score on the assertiveness scale. & Robinson (1990) \\
\hline $\begin{array}{l}\text { Caregivers who were trained in SS or in behavioral management strategies had lower perceptions of burden and } \\
\text { more positive attitudes in relation to asking for help and requesting care provider services when compared to } \\
\text { other caregivers. }\end{array}$ & $\begin{array}{l}\text { Robinson and Yates } \\
\text { (1994) }\end{array}$ \\
\hline Caregivers who were more assertive had lower perceptions of burden. & Muela et al. (2001) \\
\hline $\begin{array}{l}\text { Caregivers who received SS training and guidance on how to manage stress showed a decrease in their } \\
\text { perceptions of burden and an increase in their perceptions of quality of life. }\end{array}$ & Faleiros (2009) \\
\hline $\begin{array}{l}\text { Caregivers who received SS training reported lower stress and improved their SS scores, following the training } \\
\text { program. }\end{array}$ & Dornelles (2010) \\
\hline $\begin{array}{l}\text { Paid caregivers working in an institution setting who had higher scores on the social competence instrument had } \\
\text { lower perceptions of stress. }\end{array}$ & $\begin{array}{l}\text { Franzmann et al. } \\
\text { (2014) }\end{array}$ \\
\hline $\begin{array}{l}\text { There was no significant relationship between social skills and emotional intelligence. However, caregivers } \\
\text { reported feeling better prepared to manage the daily activities related to their older relative. }\end{array}$ & $\begin{array}{l}\text { Maciá and López } \\
\text { (2014) }\end{array}$ \\
\hline $\begin{array}{l}\text { Caregivers who helped an older relative with dementia reported higher perceptions of burden, greater difficulty } \\
\text { in accepting criticism, and greater problems with emotional self-control than caregivers who assisted a } \\
\text { dependent older relative with no signs of dementia. }\end{array}$ & $\begin{array}{l}\text { Pinto and Barham } \\
(2014 a)\end{array}$ \\
\hline $\begin{array}{l}\text { Caregivers who said they used coping strategies and social skills more frequently reported fewer conflicts with } \\
\text { the older adult who they were caring for. }\end{array}$ & $\begin{array}{l}\text { Pinto and Barham } \\
\text { (2014b) }\end{array}$ \\
\hline $\begin{array}{l}\text { The main conflicts involved in the context of caring for an older adult were differences of opinions and } \\
\text { financial issues. The social skills considered most important were: expressing positive feelings, controlling } \\
\text { aggressiveness, and discussing problems. }\end{array}$ & Pinto et al. (2016) \\
\hline
\end{tabular}

\section{Discussion}

In this study, we examined the existing scientific literature to determine what evidence exists concerning the relationship between the social skills of those who care for older relatives and indicators of their psychosocial adjustment. Based on the information found, we noted that few studies have been conducted and most studies on this topic are recent.This may may reflect the growth of the older adult population, and consequently, the increased need for caregivers. The most commonly reported finding is that more frequent use of social skills is related to lower perceptions of burden. This result is important because studies such as those conducted by Tomomitsu et al. (2014) and Wang et al. (2014) show that caregivers are more likely than non-caregivers to experience moderate to severe levels 
of burden and poorer levels of physical and psychological health. These changes may be due to higher financial costs for meeting the needs of the older adult, reduced time to care for their own health or for other valued activities, higher tensions in the family around sharing the responsibilities of taking care of the older relative, among others (Pinto, 2016; Tomomitsu et al., 2014; Wang et al., 2014). Caregivers with greater social competence seem to have a greater capacity to garner practical support and to establish relationships where they can share the concerns and joys of caregiving, as discussed by Bandeira et al. (2014) and Lima, Bandeira, Oliveira, and Tostes (2014).

The studies conducted by Pinto and Barham (2014b) and Pinto et al. (2016) exemplify how important social skills may be for controlling negative reactions, and for maintaining and building stronger relationships. According to the authors, social skills may help caregivers adapt to their new role in two key ways: (a) by controlling negative reactions to new demands that arise in this context, since caregivers often need to reduce their participation in other activities of personal importance to take on increasing levels of responsibility for caring for their older relative; and (b) by interacting positively with others, even in difficult circumstances, so they can enjoy positive accomplishments and interactions during this period of their lives. This evidence corroborates other findings based on intervention work with other populations, indicating that the ability to use a wide repertoire of social skills is a condition that can favor socially competent behaviors (A. Del Prette \& Z.A.P. Del Prette, 2017). Thus, it may also be worthwhile to invest in helping caregivers to think about how to consider the personal differences, cultural issues, and even geographic factors that affect the involvement of family members, friends and professionals in the care for older adults.

In several of the studies reviewed, social skills training programs were offered (Dornelles, 2010; Faleiros, 2009; Maciá \& López, 2014; Robinson, 1988; Robinson \& Yates, 1994). Identifying effective ways to help caregivers become more socially competent in their role is a task of the utmost importance. Caregivers who can assertively ask for help, say no to unreasonable requests, admit a mistake, ask someone to change a behavior that leads to problems, deal with criticism, understand other people's perspectives, offer support, mediate conflicts, and express positive feelings create a much more positive interpersonal environment, as discussed by Pinto et al. (2016). Caregivers who can set their negative feelings aside and direct their attention to finding solutions will probably think of alternative ways of assisting their dependent, older family member, that are better tailored to the possibilities and limitations of each person in their support network. This principle may also lead to a better integration of the efforts of both family members and formal caregivers (e.g., paid care providers, nurses, and doctors), as discussed by Zwaanswijk et al. (2013). Moreover, when the primary caregivers take the needs of other family members into consideration, these people are more likely to maintain a positive relationship with the caregivers, which may increase the likelihood that these family members will notice other things they could do to help their older family member, further contributing to positive interactions.

In summary, this literature review was based on the observation that, in addition to relying on new information and assistive technologies in the field of gerontology, evaluating the contribution of interpersonal factors that affect how one experiences caring for a dependent older adult is fundamental. Psychologists and other healthcare professional can probably help caregivers develop more competent social strategies to cope with the demands that so commonly arise in this context. By using such an approach it may be possible to improve caregivers' interpersonal relationships and their overall well-being, since in other contexts already investigated, people who are more socially skilled report a better quality of life and stronger interpersonal relationships (A. Del Prette \& Z.A.P. Del Prette, 2017; Lima et al., 2014; Pinto \& Barham, 2014a, 2014b).

However, we must emphasize that the studies we reviewed presented a consistent methodological limitation. No researchers used an instrument for evaluating social skills that was specifically developed for the caregiving context. As described by other researchers (A. Del Prette \& Z.A.P. Del Prette, 2017; Pinto \& Barham, 2014a, 2014 b), although a person may be socially competent in working with others to respond to the demands that exist in a context such as a paid work situation (where norms of meritocracy prevail), this person will need to learn new behaviors to establish and manage the social interactions that are involved in another context, such as caring for an older relative (where norms of necessity should guide one's behavior).

Given the importance of finding effective ways to help caregivers to develop specific skills that are needed when caring for older adults, the use of new instruments like the Social Skills Inventory for Family Caregivers of the Elderly will be important (Queluz, Barham, Del Prette, Fontaine, \& Olaz, 2017). Instruments such as this one can be used to identify the strengths and weaknesses in respondents' interpersonal skills for managing demands that usually occur when caring for an older family member. Using these instruments improves the capacity of researchers to evaluate the effectiveness of interventions that aim to improve caregivers' social skills repertoire, and to more accurately investigate the extent to which such improvements can contribute to increasing the wellbeing of caregivers.

Finally, the studies included in this review were published in English, Portuguese or Spanish. If the review had included publications in additional languages, it might have been possible to pinpoint some of the cultural factors that may influence the relationship between social skills and psychosocial adjustment among caregivers, as discussed by researchers from other areas who compare data collected 
in different cultural contexts (Bernal, Jiménez-Chafey, \& Domenech Rodríguez, 2009).

The absolute and proportional number of frail older adults in the population continues to increase, and recent studies on household and healthcare plan expenditures document how costly this task is (Kelley, McGarry, Gorges, \& Skinner, 2015). Therefore, finding effective ways to improve our ability to handle this responsibility is an urgent social demand. Given the importance of this task and based on the results of this study, we suggest that, in future research, efforts should be made to develop and evaluate social skills intervention programs that are tailored to the needs of caregivers of older relatives.

\section{References}

Bandeira, M., Tostes, J. G. A., Santos, D. C. S., Lima, D. C., \& Oliveira, M. S. (2014). Sobrecarga de familiares cuidadores de pacientes psiquiátricos: Relação com assertividade [Burden among family caregivers of psychiatric patients: Relation with assertive behavior]. Psico-USF, 19(3), 399-409. doi:10.1590/1413-82712014019003003

Bernal, G., Jiménez-Chafey, M. I., \& Domenech Rodríguez, M. M. (2009). Cultural adaptation of treatments: A resource for considering culture in evidence-based practice. Professional Psychology: Research and Practice, 40(4), 361-368. doi:10.1037/a0016401

Broese van Groenou, M. I., de Boer, A., \& Iedema, J. (2013). Positive and negative evaluation of caregiving among three different types of informal care relationships. European Journal of Ageing, 10(4),301-311. doi:10.1007/ s10433- 013-0276-6

Carneiro, R. S., \& Falcone, E. (2013). O desenvolvimento das habilidades sociais em idosos e sua relação na satisfação com a vida. Estudos de Psicologia, 18(3), 517-523. doi: 10.1590/S1413-294X2013000300012

Del Prette, A., \& Del Prette, Z. A. P. (2017). Competência Social e Habilidades Sociais: Manual Teórico-prático [Social Competency and Social Skills: A Theoreticalpractical Guide]. Petrópolis, RJ: Vozes.

Dornelles,A. R.A. (2010). Uma intervenção psicoeducativa com cuidadores de idosos com demência [A psychoeducational intervention with caregivers of elderly people with dementia] (Master's Thesis). Retrieved from https://repositorio.ufscar. $\mathrm{br} / \mathrm{bitstream} /$ handle/ufscar/6009/2969.pdf?sequence=1

Faleiros, D. A. M. (2009). Cuidadores de idosos com doença de Alzheimer: Efeitos de grupos psico-educacionais e suporte domiciliar individualizado [Caregivers of elderly people with Alzheimer's disease: Effects of psycho-educational groups and individualized home support] (Master's Thesis). Retrieved from https://repositorio.ufscar.br/ bitstream/handle/ufscar/3013/2397.pdf?sequence $=1$
Franzmann, J., Krause, K., Haberstroh, J., \& Pantel, J. (2014). Assessment of self-perceived social competencies of caregivers in dementia care: Development and psychometric testing of the SOKO dementia. GeroPsych: The Journal of Gerontopsychology and Geriatric Psychiatry, 27(2), 67-73. doi:10.1024/16629647/a000103

Garces, S. B. B., Krug, M. R., Hansen, D., Brunelli, A. V., Costa, F. T. L., Rosa, C. B., Bianchu, P. D., Mattos, C. M. Z., \& Seibel, R. (2012). Avaliação da resiliência do cuidador de idosos com Alzheimer. Revista Brasileira de Geriatria e Gerontologia, 15(2), 335-352. doi: 10.1590/ S1809-98232012000200016

Grossman, M. R., \& Gruenewald, T. L. (2017). Caregiving and perceived generativity: A positive and protective aspect of providing care? Clinical Gerontologist, 40(5), 435-447. doi:10.1080/07317115.2017.1317686

Kelley, A. S., McGarry, K., Gorges, R., \& Skinner, J. S. (2015). The burden of health care costs for patients with dementia in the last 5 years of life. Annals of International Medicine, 163(10), 729-736. doi:10.7326/M15-0381

Li, R., Cooper, C., Bradley, J., Shulman, A., \& Ryan, G. (2012). Coping strategies and psychological morbidity in family carers of people with dementia: A systematic review and meta-analysis. Journal of Affective Disorders, 139(1), 1-11. doi: 10.1016/j.jad.2011.05.055

Lima, D. C., Bandeira, M., Oliveira, M. S., \& Tostes, J. G. A. (2014). Habilidades sociais de familiares cuidadores de pacientes psiquiátricos [Social skills of family caregivers of psychiatric patients]. Estudos de Psicologia (Campinas), 31(4), 549-558. doi:10.1590/0103-166X2014000400009

Maciá, E. S., \& López, B. B. (2014). Desarrollo de un programa psicoeducativo en inteligencia emocional para cuidadores principales de enfermos de Alzheimer [Development of a psychoeducational program in emotional intelligence for primary caregivers of Alzheimer's patients]. European Journal of Investigation in Health, Psychology and Education, 4(3), 257-266. doi:10.1989/ejihpe.v4i3.73

Muela, J. A., Torres, C. J., \& Peláez, E. M. (2001). La evaluación de la asertividad como predictor de carga en cuidadores de enfermos de Alzheimer [Assessment of assertiveness as a predictor of burden in caregivers of Alzheimer's patients]. Revista Española de Geriatría $y$ Gerontología, 36(1), 41-45. doi:10.1016/S0211139X(01)74681-1

Pearlin, L. I., Mullan, J. T., Semple, S. J., \& Skaff, M. M. (1990). Caregiving and the stress process: An overview of concepts and their measures. The Gerontologist, 30(5), 583-594. doi:10.1093/geront/30.5.583 
Pinquart, M., \& Sörensen, S. (2011). Spouses, adult children, and children-in-law as caregivers of older adults: A metaanalytic comparison. Psychology and Aging, 26(1), 1-14. doi: $10.1037 / \mathrm{a} 0021863$

Pinto, F. N. F. R. (2016). Violência contra o idoso: Uma discussão sobre o papel do cuidador [Violence against the elderly: A discussion about the role of caregiver]. Revista Kairós Gerontologia, 19(2), 107-119. Retrieved from https://revistas.pucsp.br/index.php/kairos/article/ viewFile/30119/20879

Pinto, F. N. F. R., \& Barham, E. J. (2014a). Bem-estar psicológico: Comparação entre cuidadores de idosos com e sem demência [Psychological wellbeing: A comparison between caregivers of older adults, with and without dementia]. Psicologia, Saúde \& Doenças, 15(3), 635-655. doi:10.15309/14psd150307

Pinto, F. N. F. R., \& Barham, E. J.(2014b). Habilidades sociais e estratégias de enfrentamento de estresse: Relação com indicadores de bem-estar psicológico em cuidadores de idosos de alta dependência [Social skills and coping strategies: Their relationship with psychological wellbeing among caregivers of highly dependent elderly people]. Revista Brasileira de Geriatria e Gerontologia, 17(3), 525-539. doi:10.1590/1809-9823.2014.13043

Pinto, F. N. F. R., Barham, E. J., \& Albuquerque, P. P. (2013). Idosos vítimas de violência: Fatores sociodemográficos e subsídios para futuras intervenções [Elderly victims of violence: Sociodemographic factors and information for future interventions]. Estudos e Pesquisas em Psicologia, 13(3), 1159-1181. Retrieved from http://pepsic. bvsalud.org/scielo.php?script=sci_arttext\&pid $=\mathrm{S} 1808$ 42812013000300018

Pinto, F. N. F. R., Barham, E. J., \& Del Prette, Z. A. P. (2016). Interpersonal conflicts among family caregivers of the elderly: The importance of social skills. Paidéia (Ribeirão Preto), 26(64), 161-170. doi:10.1590/198243272664201605

Queluz, F. N. F. R., Barham, E. J., Del Prette, Z. A. P., Fontaine, A. M. G. V., \& Olaz, F. O. (2017). Inventário de Habilidades Sociais para Cuidadores de Idosos (IHSCI): Evidências de validade [The Social Skills Inventory for Caregivers of Elderly Family Members (SSI-CE): Evidence of validity]. Avaliação Psicológica, 16(1), 78-86. doi:10.15689/ap.2017.1601.09

Robinson, K. (1988). A social skills training program for adult caregivers. Advances in Nursing Science, 10(2), 5972. doi:10.1097/00012272-198801000-00010

Robinson, K. (1990). The relationships between social skills, social support, self-esteem and burden in adult caregivers. Journal of Advanced Nursing, 15(7), 788-795. doi:10.1111/j.1365-2648.1990.tb01908.x
Robinson, K., \& Yates, K. (1994). Effects of two caregivertraining programs on burden and attitude toward help. Archives of Psychiatric Nursing, 8(5), 312-319. doi:10.1016/0883-9417(94)90029-9

Scheufler, L., Braz, A. C., Pacheco, J. T. B., Oliveira, C. R., Gonzatti, V., Argimon, I. I. L., ... Irigaray, T. Q. (2017). Are social skills related to sociodemographic variables and depressive symptoms? A cross-sectional study with elderly sample. Ageing International, 42(4), 413-428. doi:10.1007/s12126-016-9260-8

Tomomitsu, M. R. S. V., Perracini, M. R., \& Neri, A. L. (2014). Fatores associados à satisfação com a vida em idosos cuidadores e não cuidadores [Factors associated with life satisfaction among elderly people who are caregivers and non-caregivers]. Ciência \& Saúde Coletiva, 19(8), 3429-3440. doi:10.1590/1413-81232014198.13952013

Tolkacheva, N., Broese van Groenou, M., \& van Tilburg, T. (2014). Sibling similarities and sharing the care of older parents. Journal of Family Issues, 35(3), 312-330. doi:10.1177/0192513X12470619

Wang, X. R., Robinson, K. M., \& Carter-Harris, L. (2014). Prevalence of chronic illnesses and characteristics of chronically ill informal caregivers of persons with dementia. Age and Ageing, 43(1), 137-141. doi:10.1093/ageing/aft142

Weinbrecht, A., Rieckmann, N., \& Renneberg, B. (2016). Acceptance and efficacy of interventions for family caregivers of elderly persons with a mental disorder: A meta-analysis. International Psychogeriatrics, 28(10), 1615-1629. doi:10.1017/S1041610216000806

Yıkılkan, H., Aypak, C., \& Görpelioğlu, S. (2014). Depression, anxiety and quality of life in caregivers of long-term home care patients. Archives of Psychiatric Nursing, 28(3), 193-196. doi:10.1016/j.apnu.2014.01.001

Zwaanswijk, M., Peeters, J. M., van Beek, A. P. A., Meerveld, J. H. C. M., \& Francke, A. L. (2013). Informal caregivers of people with dementia: Problems, needs and support in the initial stage and in subsequent stages of dementia: A questionnaire survey. The Open Nursing Journal, 7, 6-13. doi:10.2174/1874434601307010006

Francine Náthalie Ferraresi Rodrigues Queluz is a Postdoc Researcher of the Universidade São Francisco, CampinasSP, Brazil.

Elizabeth Joan Barham is a Professor of Universidade Federal de São Carlos, São Carlos-SP, Brazil.

Zilda Aparecida Pereira Del Prette is a Professor of Universidade Federal de São Carlos at the Instituto Nacional de Ciência e Tecnologia sobre Comportamento, Cognição e Ensino, São Carlos-SP. 


\section{Authors' Contribution:}

All authors made substantial contributions to the conception and design of this study, to data analysis and interpretation, and to the manuscript revision and approval of the final version. All the authors take public responsibility for the content of the manuscript.

Received: May. 10, 2017.

1st Revision: Nov. 27, 2017

Approved: Apr. 11, 2018

How to cite this article:

Queluz, F. N. F. R., Barham, E. J., \& Del Prette, Z. A. P. (2019). The relationship between social skills and psychosocial adjustment among those who care for older adults. Paidéia (RibeirãoPreto), 29, e2917. doi: http://dx.doi.org/10.1590/1982-4327e2917 